\title{
Chickenpox during pregnancy
}

\section{Zoster immune globulin for appreciable exposure; acyclovir for progressive infection}

Most people in developed countries are infected with varicella zoster virus and develop chickenpox during childhood with no more than minor inconvenience. The few who develop infection later in life have a disproportionate share of serious complications. Although only about $2 \%$ of reported cases of chickenpox occur in people over 20, these cases account for one quarter of all deaths from the disease and are usually due to varicella pneumonia. ${ }^{1}$ Severe primary varicella often occurs in immunocompromised patients, especially those with cell mediated immune deficiency, in whom there is also an increased risk of reactivation of latent infection, manifested by herpes zoster.

The coincidence of chickenpox with pregnancy is uncommon, occurring in an estimated one in 2000 pregnancies in the United States. Contact with an infected person, however, is not infrequent and causes concern for the welfare of the pregnant woman and her fetus. The common perception that chickenpox is generally more severe in pregnant women than in others of the same age may partly reflect a bias towards reporting of more severe cases during pregnancy. Thus in cases reported up to 1963 the mortality was $41 \%{ }^{2}$ although in three prospective studies only two deaths occurred among nearly 200 patients. ${ }^{3-5}$ The mild immunosuppression associated with pregnancy is probably one of several factors that determine the severity of chickenpox in pregnancy.

Despite uncertainty about the specific effect of pregnancy severe varicella occurs in pregnant women as in other adults. Rarely this causes fetal death or premature labour, both of which are non-specific effects related to the severity of maternal illness rather than to fetal infection. ${ }^{5}$ In a few cases, unrelated to the severity of maternal infection, varicella virus crosses the placenta and infects the fetus. There is no overall increase in the incidence of congenital abnormality associated with maternal varicella, ${ }^{6}$ but fetal infection can cause a characteristic syndrome, first described in $1947 .{ }^{7}$ The most typical features are hypoplasia of one limb and cicatricial lesions with a dermatomal distribution affecting the same limb. Neurological abnormalities (hydrocephalus and microcephaly) and eye abnormalities (Horner's syndrome, cataracts, chorioretinitis, and microphthalmia), functional or structural defects of the gastrointestinal and genitourinary tracts, and growth retardation have also been described. ${ }^{8-10}$

Several prospective studies suggest that the risk of the fetal varicella syndrome after maternal varicella in the first trimester is about $3 \%{ }^{4511}$; there have been only isolated reports of damage after maternal varicella in the second or third trimester or after maternal zoster. ${ }^{12}$ Varicella virus has not been isolated from affected infants, suggesting that fetal infection is not persistent (in contrast with intrauterine rubella or cytomegalovirus infection). Because of the dermatomal distribution of skin scarring and focal limb hypoplasia it has been postulated that fetal damage, at least in some cases, results from reactivation of latent infection with or without encephalitis (analogous to herpes zoster) and abnormal development of structures supplied by affected nerves. ${ }^{9}$ Typical herpes zoster occasionally occurs in the first few months of life in otherwise normal infants exposed to intrauterine varicella, reflecting failure of the immature immune system to maintain viral latency; it is usually benign. ${ }^{13}$ Presumably any damage caused by reactivation depends on the site and the stage of development of affected tissue.

Maternal infection late in pregnancy is associated with perinatal infection in $20-60 \%$ of cases. ${ }^{451415} \mathrm{~A}$ rash may be present at birth or develop within a few days. Neonatal infection is usually mild, but when the onset of maternal infection occurs between about five days before and two days after delivery it may be more severe, with a relatively short incubation period (mean 11 days) and onset at 5 to 10 days of age. A mortality of $20-30 \%$ has been recorded but may have been exaggerated by selective reporting. ${ }^{14}$ It has been postulated that severe infection is due to exposure of the fetus to a large viral inoculum without the protection of maternal antibody. The severity of infection, however, correlates poorly with antibody concentrations, and other factors, including the immaturity of the cell mediated immune response, probably contribute. ${ }^{15}$

Although incomplete, these data are the basis for counselling and managing pregnant women exposed to or suffering from varicella. Pregnant women who are believed to be susceptible (on the basis of history and, preferably, assay of serum antibodies) and have had appreciable exposure to chickenpox should be given zoster immune globulin. Although this can prevent or modify clinical varicella if given up to four days after contact, there is no evidence that it prevents fetal infection or damage. As the risk of fetal damage is small and unpredictable, termination of pregnancy because of maternal varicella is not indicated. There is little experience with intrauterine diagnosis, but severe fetal damage should be detectable by ultrasound examination. ${ }^{10}$

Zoster immune globulin is also recommended for infants of women who develop chickenpox within a few days of (before or after) delivery. Among 176 infants whose mothers 
developed varicella within a week of delivery and were given globulin, 105 developed clinical varicella, which was severe in 16 , but there were no deaths. ${ }^{15}$ There were no controls, but the data suggest that the severity of infection, if not the attack rate, can be reduced by the use of zoster immune globulin. Failures of treatment have, however, been reported, and no relation seems to exist between the dose of zoster immune globulin and the severity of neonatal varicella. ${ }^{1516}$ Severe or progressive maternal or neonatal infection should be treated with intravenous acyclovir, which is safe and can improve the outcome appreciably. ${ }^{15}$ Prevention of chickenpox during pregnancy is clearly desirable and would be a major benefit of the use of varicella vaccines in future.

GWENDOLYN L GILBERT

Centre for Infectious Diseases and Microbiology,

Clinical professor, infectious diseases

University of Sydney, Westmead Hospital,

Westmead, NSW 2145, Australia
1 Preblud SR. Age-specific risk of varicella complications. Pediatrics 1981;68:14-7.

2 Harris RE, Rhoades ER. Varicella pneumonia complicating pregnancy. Obstet Gynecol 1965;25:734-40.

3 Seigel M, Fuerst HT, Peress NS. Comparative fetal mortality in maternal virus diseases. $N$ Engl $\mathfrak{f}$ Med 1966;274:768-71.

4 Enders G. Varicella-zoster infection in pregnancy. Prog Med Virol 1984;29:166-96.

5 Paryani SG, Arvin AM. Intrauterine infection with varicella-zoster virus after maternal varicella. N Engl I Med 1986;314:1542-6.

6 Sever J, White LR. Intrauterine viral infections. Annu Rev Med 1965;19:471-86.

7 LaForet EG, Lynch CL. Multiple congenital defects following maternal varicella. N Engl f Med 1947;236:534-7.

8 Alkalay AL, Pomerance JJ, Rimoin DL. Fetal varicella syndrome. f Pediatr 1987;111:320-3.

9 Higa K, Dan K, Manabe H. Varicella-zoster virus infection during pregnancy: hypothesis concerning the mechanisms of congenital malformations. Obstet Gynecol 1987;69:214-22.

10 Balducci J, Rodis JF, Rosengren S, Vintzilcos AM, Spivey G, Vosseller C. Pregnancy outcome following first-trimester varicella infection. Obstet Gynecol 1992;79:5-6.

11 Preblud SR, Cochi SL, Orenstein WA. Varicella-zoster infection in pregnancy. $N$ Engl $f$ Med 1986;315:1416-7.

12 Gershon AA. Chicken pox, measles and mumps. In: Remington JS, Klein JO, eds. Infectious diseases of the fetus and newborn infant. 3rd ed. Philadelphia: W B Saunders, 1990:395-445.

13 Brunell PA, Kotchmer GS. Zoster in infancy: failure to maintain virus latency following intrauterine infection. I Pediatr 1981;98:71-3.

14 Meyer JD. Congenital varicella in term infants: risk reconsidered. F Infect Dis 1974;129:215- 7 .

15 Miller E, Cradock-Watson JE, Ridehalgh MKS. Outcome in newborn babies given antivaricella-zoster immunoglobulin after perinatal maternal infection with varicellazoster virus. Lancet 1989;ii:371-4.

16 Preblud PA. Varicella in pregnancy, the fetus and newborn: problems in management. $f$ Infect Dis 1992;166(suppl 1):S42-7.

\section{Restorative gardens}

\section{Green thoughts in a green shade}

Recent research in environmental psychology is now giving encouragement to the call for the revival of the old tradition of providing gardens for hospital patients. Although little progress has been made in the United States, where the research has been centred, the United Kingdom seems to be leading the revival.

Psychologists have determined that the tunnel corridors, clutter of equipment, frightening medical machinery, blank walls, dreary views, noise, and harsh lighting that characterise modern hospitals are all environmental factors that increase blood pressure, heart rate, and the endocrine responses that accompany anxiety, fear, and anger. ${ }^{1}$ By contrast, views of trees, lawns, flowers, and water promote healing by encouraging an attentive state that reduces tension and fatigue. ${ }^{2}$

These studies thus rediscover techniques long practised, but often neglected. In the West the provision of gardens for hospital patients dates from the courtyards of the mediaeval hospices that flourished both in England and the Continent. During the Renaissance and the Reformation hospitals became charitable institutions for plague victims and the poor. Then it was a rare establishment that provided gadens for the emotional restoration of patients. When John Howard made his survey he found only two British hospitals that met his garden criteria. ${ }^{3}$ Howard commented favourably on the provision of gardens at St George's for the Sick and Lame and the British Lying-In Hospital in London, but he particularly admired the Santa Maria Nova in Florence.

During the late eighteenth and early nineteenth centuries a fusion of Romantic ideas about nature, democratic ideas about the treatment of the poor, and antiseptic ideas about the treatment of the sick merged to call forth new hospital designs. Mental hospitals were built with gardens, and many acute and chronic care hospitals had gardens between their two and three storey pavilions. The City and County Asylum in Hereford (1868-71) and the London County Council Asylum at Claybury, Essex (1901), are typical of the mental hospital plans; while the Herbert Military Hospital, Woolwich (1861-5), built for Florence Nightingale, and the Leeds General Infirmary (1864) show the way that gardens worked in the new pavilion style. ${ }^{4}$

More recently the discovery of antibiotics and the advance of high technology diagnostics and surgery have led to shorter hospital stays and neglect of the patient's experience while in hospital. Most big city hospitals now resemble office buildings more than sunny rooms surrounded by gardens. In the United States there are only a very few small hospitals that meet the current criteria for having good gardens. These criteria are: window sills low enough so patients can see the gardens and not just the tops of trees from their beds; a regular programme to allow patients in wheelchairs access to the gardens; a green walking space for those recovering from one day or short stay surgery; a variety of open and closed spaces; and gardens for staff and visitors. A good hospital thus offers several gardens, some open and some enclosed, some for patients only, some shared with staff and visitors.

One American hospital that meets all these criteria is the Wausau Hospital Center in Wausau, Wisconsin. Several British hospitals fulfill most of the criteria but probably none satisfies all five. Among the best examples is West Dorset Hospital, Dorchester, which has a variety of excellent gardens and won the Astra arts award for the best art in British hospitals in 1990 for its bird garden, containing both craftwork and sympathetic planting: its window sills were deliberately kept to a height of $630 \mathrm{~mm}$ to give patients a view down into the courtyard gardens. The County Hospital in Lincoln recently turned its courtyard into a garden, with the aim that patients should maintain it. It has access from the day hospital, from the electroconvulsive therapy suite, and, for wheelchairs, from the corridor. The first floor day area, staff room, and wards also look down onto the garden, but alas the window sills are too high for patients to see the gardens from their beds.

The Edward Street Hospital, West Bromwich, has a series of enclosed gardens; some provide quiet sitting areas for patients and visitors, and one is a rehabilitation garden with different surfaces for patients to walk on and raised flower beds for patients to do their own planting. The Stoke City General Hospital, a nucleus design, has interesting courtyards landscaped like Japanese water gardens with floor to ceiling glazing for optimal views. There are garden sitting areas for staff; a children's play area is safely enclosed but with views out to the countryside; and a once marshy ravine to the south 